TITLE:

\title{
Effective islet isolation method with extremely high islet yields from adult pigs(Abstract_要旨)
}

AUTHOR(S):

Yonekawa, Yukihide

\section{CITATION:}

Yonekawa, Yukihide. Effective islet isolation method with extremely high islet yields from adult pigs. 京都大学, 2006, 博士(医学)

\section{ISSUE DATE:}

2006-03-23

URL:

http://hdl.handle.net/2433/143813

RIGHT: 


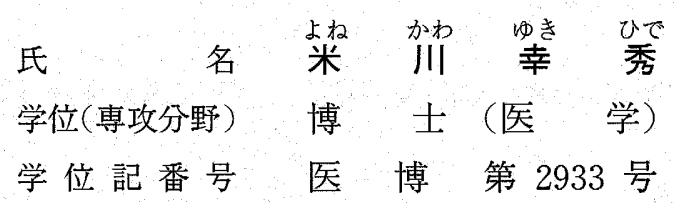

学位授与の日付平成 18 年 3 月 23 日

学位授与の要件 学 位 規 則 第 4 条第 1 項 該 当

研究科. 專攻医学研究科外科系専攻

学位論文題目 Effective islet isolation method with extremely high islet yields from adult pigs

（ブタ膵島大量分離法の開発——成熟ブタを用いた効果的分離法——）

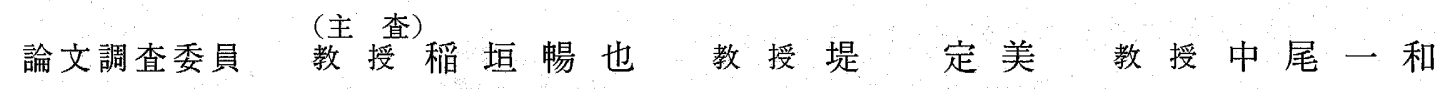

\section{論 文内容 の 要 旨}

臨床膵島移植の成功に最も重要な要素の一つが脺島分離である。ブ夕膵臓は解剖学的・生理学的にヒト膵臓に近いため, 膵島分離の研究に最適と考えられている。今回成熟ブタを用いた新しいブ夕膵島大量分離法 (以下 N 法) を開発し，過去 にサル膵島分離法として発表されているOpen pan 法（以下 $\mathrm{O}$ 法）およびヒト膵島分離の標準である Ricordi 法（以下 $\mathrm{R}$ 法）による分離成績と比較した。

$\mathrm{N}$ 法 5 例， $\mathrm{O}$ 法 5 例， $\mathrm{R}$ 法 5 例，計15例のブタ膵島分離を行った。いずれの方法でもコラゲナーゼによる「膵臓消化」, 次いで密度勾配遠心分離による「膵島純化」の段階を経るが，N法では以下の工夫を行い，他法とは違い全膵を利用した 膵島分離に成功した。すなわち, 膵臓摘出時に膵管内へ臓器保存液を注入したこと, 膵管内へのコラゲナーゼ注入時にも全 膵形態を温存し分断しなかったこと, コラゲナーゼとしてヒト用の「Liberase HI」をR 法の $1 / 3$ と低濃度で用い，膵臟消 化に比較的長時間の静置消化法を採用したこと, 全膵消化内容をろ過するために大容量のろ過器を開発したこと, 膵島純化 にあたっても大容量ボトルを使用したことである。いずれの方法による分離膵島も, 収量, 純度, viability, そしてin vit$r o$ 機能評価を行った。 $\mathrm{N}$ 法で分離した膵島は in vivo 機能評価のために糖尿病化 SCID マウスの腎被膜下に移植した（ $\mathrm{n}=$ 8)。

$\mathrm{N}$ 法では 1 膵臓あたり純化前で 1,236,266 213,486 Islet Equivalent (以下 IE) (mean $\pm \mathrm{SE}$ )，純化後で 879,815 $222,729 \mathrm{IE}$ の収量を得た。O 法抢よび $\mathrm{R}$ 法では 1 脺臓あたりの純化後収量はそれぞれ $30,666 \pm 11,532 \mathrm{IE}, 317,073 \pm$ 86,093 IE であり， N 法は $\mathrm{O}$ 法の約25倍, $\mathrm{R}$ 法の約2.5倍以上と有意に収量が高かった $(\mathrm{P}<0.01 ， \mathrm{P}<0.05) 。$ 脺臓 $1 \mathrm{~g}$ あた

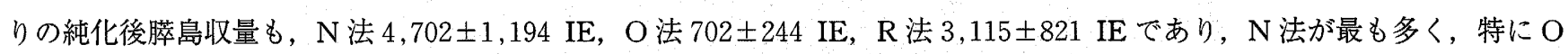
法に比して有意に収量が高かった（P<0.01）。 N 法と R 法の収量の差は， R 法では消化に用いる膵臓の容量制限（約 $120 \mathrm{~g}$ ）があるのに対し，N法では全膵を膵島分離に利用できることが主な原因と考えられた。

純度は 3 法のうちO法で有意に低く, viability は 3 法間で有意差はなかった。in vitro 機能評価としてのブドウ糖負荷 Stimulation Index も 3 法間で有意差はなかった。

$\mathrm{N}$ 法で分離したブ夕膵島 1000 個を腎皮膜下に移植された糖尿病 SCID マウスは, 全例4日以内に糖尿病が治癒し, ブドウ 糖負荷試験による耐糖能も正常となった。またグラフト摘出による糖尿病の再発も確認され, 糖尿病治癒が移植膵島の効果 であることが証明された。

$\mathrm{N}$ 法では全膵を利用して, 機能的にもすぐれた大量のブタ脺島を分離することができた。膵臓摘出時の膵管内への臟器 保存液注入，およびコラゲナーゼ注入時の全膵形態温存などの工程はヒト膵島分離にも応用できると考えられた。また，将 来的に異種移植をブタのシングルドナーで行うとすれば，全膵を無駄なく膵島分離に利用して大量の膵島を得ることができ る本法は有用であると考えられた。 


\section{論 文 審 査 $の$ 結 果 $の$ 要 旨}

本論文の目的は, ヒト膵臓に解剖学的・生理学的に近いブタ膵臓からの新しい膵島分離法 (以下本法) を開発し, 最終的 には臨床膵島分離に還元することである。

本法によるブ夕膵島分離成績を, サル膵島分離法として開発されたOpen pan 法, およびとト膵島分離の標準である Ricordi 法によるものと比較した。他法では膵島分離に利用できる膵臓容積に制限があるのに対し，本法では全萃を利用で きるよう脺臓を分断せず，形体を温存したまま膵管内へ臓器保存液およびョラゲナーゼを注入，これに大容量のろ過・純化 装置を組み合わせた。

結果として本法では 1 頭のブタから平均約80万 IE（Islet Equivalent）と Open pan 法の約25倍, Ricordi 法の約2.5倍と 有意に高い脺島収量が得られた。分離膵島の in vitro 機能試験の結果は良好で，糖尿病マウスへの移植では血糖を90日にわ たって正常化させ，良質の膵島であることが示された。

本法のいくつかの工程は臨床膵島分離にも応用可能と考えられた。また，1頭のブタから平均約 80 万 IE の膵島が得られ たため，拒絶反応が克服できればシングルドナー異種膵島移植の可能性が示唆される。シングルドナーにすることは，感染 および拒絶の可能性がいずれも減少するので極めて重要と考えられる。

以上の研究は膵島分離法の開発に貢献し, 糖尿病治療としての膵島移植の発展に寄与するところが多い。

したがって，本論文は博士 (医学) の学位論文として価値あるものと認める。

なお，本学位授与申請者は，平成17年12月19日実施の論文内容とそれに関連した試問を受け，合格と認められたものであ る。 